https://doi.org/10.18485/iipe_regbezb.2021.ch5

\title{
ZAPADNI BALKAN: IZMEĐU KONFLIKTA I STABILNOSTI
}

\begin{abstract}
Nevena ŠEKARIĆ
Apstrakt: S obzirom na kompleksnu istorijsku, političku i bezbednosnu prirodu Zapadnog Balkana, $u$ radu je fokus na ispitivanju transformacije ovog regiona duž spektra konfliktna formacija-bezbednosna zajednica. Kako EU predstavlja ključnog eksternog drajvera ovih transformacijskih putanja, dodatno će biti analizirana i njena uloga u ovim procesima. Stoga glavna hipoteza kojom je rukovođena analiza u ovom radu glasi: Zapadni Balkan se transformisao iz konfliktne formacije u bezbednosni režim, a uloga EU bila je ključna u tom procesu. Shodno analitičkom instrumentarijumu korišćenom prilikom istraživanja, teorijski okvir čini teorija regionalnog bezbednosnog kompleksa i njoj pripadajući pojmovi. Dok je teorijski cilj ovog rada usmeren ka doprinosu raspravi o regionalnoj bezbednosti i rasvetljavanju ključnih analitičkih alata za njeno tematizovanje, praktični cilj ogleda se u mapiranju svih onih značajnih formata saradnje između zapadnobalkanskih država i zajedničkih pretnji koje ga istovremeno dele od konfliktne formacije i svrstavaju u bezbednosni režim. Ključne metode istraživanja oličene su u vidu pregleda literature, analize sadržaja relevantnog korpusa istraživačke građe, kao i metode scenarija.

Ključne reči: Zapadni Balkan, Evropska unija, teorija regionalnog bezbednosnog kompleksa, regionalni bezbednosni potkompleks, konfliktna formacija, bezbednosni režim, bezbednosna zajednica, transformacija.
\end{abstract}

\footnotetext{
${ }^{1}$ Istraživač saradnik, Institut za međunarodnu politiku i privredu, Beograd.

E-mail: nevena.sekaric@diplomacy.bg.ac.rs

Rad je nastao u okviru naučnoistraživačkog projekta „Srbija i izazovi u međunarodnim odnosima 2021. godine“, koji finansira Ministarstvo prosvete, nauke i tehnološkog razvoja Republike Srbije, a realizuje Institut za međunarodnu politiku i privredu tokom 2021. godine.
} 


\section{UVODNE NAPOMENE}

Balkan je oduvek privlačio pažnju istraživača zbog svoje permanentne nestabilnosti. Istraživanja kojima se tematizuje ovaj (pod)region uglavnom ga determinišu kao nestabilno i potencijalno konfliktno područje. Počev od 90-ih godina XX veka, Zapadni Balkan je do danas prošao transformativni put od konfliktnog područja do relativno stabilnog regiona. Opterećen najpre disolucijom zajedničke države i oružanim sukobima, a potom i procesom izgradnje država, danas ga, pored postojećeg konfliktnog potencijala, karakteriše i značajan stepen stabilnosti i različitih formata saradnje koja se uspostavlja između zapadnobalkanskih zemalja.

Više studija govori $\mathrm{u}$ prilog tome da Zapadni Balkan predstavlja adekvatan naziv za regionalni bezbednosni entitet u ovom delu evropskog kontinenta (Kovačević 2011; Lipovac 2016; Kudlenko 2018; Veličkovski Stojanovski 2019). Dok šest zapadnobalkanskih država čini esenciju ovog (pod)regiona, ${ }^{2}$ glavnim međunarodnim akterima smatraju se EU, SAD, Rusija, Kina, Turska i još neke evropske države. Ovde ne treba zaboraviti ni NATO koji je odigrao presudnu ulogu u oružanim sukobima tokom 90-ih, kao ni činjenicu da su gotovo sve zapadnobalkanske zemlje članice ove Alijanse (izuzev Srbije koja se opredelila za vojnu neutralnost i Bosne i Hercegovine koja (još uvek) nije njena punopravna članica). Međutim, pretežan činilac jeste ipak Evropska unija koja, počev od 2000-ih godina, preuzima ulogu stabilizatora na Zapadnom Balkanu i predstavlja glavni cilj kretanja zapadnobalkanskih država u budućnosti, primarno shvaćen u smislu članstva u njoj.

Zapadni Balkan danas opterećuju mnoga bezbednosna pitanja, kako u regionalnom tako i u bilateralnom smislu: nerešena teritorijalna pitanja, međuetnička trvenja, nestabilne političke i ekonomske prilike, prisustvo (često oponentnih) međunarodnih aktera, kao i mnoge savremene bezbednosne pretnje poput organizovanog kriminala, korupcije, ilegalnih migracija, elementarnih nepogoda i sl. Međutim, prisutni su i određeni formati saradnje između zapadnobalkanskih država, kao i kolektivna sekuritizacija zajedničkih pretnji koja neretko rezultira udruživanjem povodom njihovog rešavanja, što sve skupa omogućava njegovo svrstavanje izvan konfliktnih formacija. Stoga

\footnotetext{
2 Šest država koje čine Zapadni Balkan su: Hrvatska, BiH, Srbija, Crna Gora, Severna Makedonija i Albanija.
} 
mapiranje ovih determinanti predstavlja primarni istraživački cilj rada, dok će, shodno prirodi ovog cilja i predmeta istraživanja, analiza biti sprovedena u svetlu teorije regionalnog bezbednosnog kompleksa (u daljem tekstu: TRBK) i njoj imanentnih pojmova.

Imajući u vidu definisan cilj i predmet istraživanja, struktura rada zamišljena je na sledeći način: nakon skiciranja glavnih postavki TRBK, sledi tematizacija Zapadnog Balkana kao zasebnog regionalnog bezbednosnog potkompleksa shodno smernicama koje nudi teorija i njeni ključni pojmovi. U tekstu će, dalje, biti dotaknuti ne samo procesi sekuritizacije prisutni unutar pojedinačnih zemalja, već i različiti formati saradnje između zapadnobalkanskih država, kao i sekuritizacija zajedničkih pretnji, a koji čine ključne kvalitativne karakteristike koje omogućavaju smeštanje ovog podregiona $u$ red bezbednosnih režima. Poseban deo posvećen je rasvetljavanju uloge EU u rekonfiguraciji Zapadnobalkanskog RBPK od konfliktne formacije ka bezbednosnom režimu, kao i mogućim scenarijima dalje transformacije ovog potkompleksa. Nakon analitičkog dela slede zaključna razmatranja i potcrtavanje glavnih nalaza koji afirmativno idu u prilog postavljenoj hipotezi.

\section{TEORIJA REGIONALNOG BEZBEDNOSNOG KOMPLEKSA: KLJUČNI POJMOVI}

Publikacija Regions and Powers: The Structure of International Security u kojoj Buzen i Vejver (Buzan and Wæver) (2003), sintetišući ključne postavke neorealizma i (socijalnog) konstruktivizma revidiraju dotadašnja teorijska promišljanja i daju najmerodavniji prikaz TRBK, postaje ključna referenca za sva dalja tematizovanja regionalne bezbednosti. ${ }^{3}$ Za razliku od drugih "regionalizama“, TRBK nudi objašnjenje regionalnih procesa i dinamike kroz bezbednosnu prizmu, tj. posmatra region ",kroz naočare bezbednosti“ (Buzan and Wæver 2003, 43-44). ${ }^{4}$ Suštinska pretpostavka TRBK jeste da pretnje lakše

\footnotetext{
${ }^{3} \mathrm{U}$ trenutku pisanja ovog teksta, platforma Google Scholar pokazala je da je pomenuta publikacija citirana 5.502 puta u najrazličitijim akademskim radovima.

${ }^{4}$ Ovo svakako ne znači da drugi „regionalizmi“" ne nude adekvatna objašnjenja različitih regionalnih procesa i odnosa - ovde je primarno akcenat na onoj bezbednosnoj strani regionalne dinamike, odnosno činjenici da su pored saradnje, nadmetanja i sukobi takođe značajni činioci interakcije koja se ostvaruje između određenih aktera.
} 
i brže putuju preko kraćih distanci te da je bezbednosna dinamika između država/jedinica na zajedničkom geografskom prostoru (susednih država, prim. aut.) dosta intenzivnija negoli između onih koje su teritorijalno udaljene (Buzan and Wæver 2003, 45). Drugim rečima, s obzirom na to da pretnje brže putuju preko kraćih distanci, bezbednosna dinamika najintenzivnija je upravo na tom regionalnom nivou. Međutim, geografska blizina (iako jedan od najznačajnijih) nije i jedini kriterijum za postojanje određenog regionalnog bezbednosnog klastera shvaćenog u terminima ove teorije - to su procesi (de)sekuritizacije. ${ }^{5}$ Stoga autori, regionalni bezbednosni kompleks (u daljem tekstu: RBK) određuju kao „grupu država čiji su procesi sekuritizacije i desekuritizacije toliko usko povezani da se ne mogu razumno analizirati ili rešavati odvojeno" (Buzan and Wæver 2003, 44). Ovi kriterijumi - geografska blizina i procesi (de)sekuritizacije - jesu ključni za formiranje bezbednosne međuzavisnosti i regionalne bezbednosne dinamike, a što je opet neophodan uslov da bi se određeni regionalni klaster mogao smatrati bezbednosnim kompleksom. Pogled na regione kroz „,bezbednosne naočare“ podrazumeva, dakle, analizu regionalnih konstelacija u kontekstu bezbednosti - $\mathrm{u}$ kontekstu procesa (de)sekuritizacije i najrazličitijih bezbednosnih problema koji pogađaju taj region. Te regionalne konstelacije i odnosi koji se uspostavljaju između država/jedinica mogu imati različit predznak, te biti prijateljski, rivalski ili pak neprijateljski, a što je posledica sprege različitih materijalnih faktora, istorijsko-političkih okolnosti, percepcije aktera i procesa (de)sekuritizacije i sl. RBK je, dakle, analitički koncept a regioni su socijalno konstruisani u smislu da su $\mathrm{u}$ najvećoj meri određeni bezbednosnim praksama ključnih aktera. Na taj način, TRBK objedinjuje teoriju sekuritizacije i sektorski pristup - procesi (de)sekuritizacije odlikuju svaki RBK i svaki RBK karakterišu različiti bezbednosni problemi koji pripadaju jednom ili više sektora bezbednosti (Veličkovski Stojanovski 2019, 3).

TRBK će u ovom radu poslužiti kao najadekvatniji teorijsko-pojmovni okvir za analizu regionalne dinamike Zapadnog Balkana iz bezbednosne perspektive. S obzirom na bogat pojmovni instrumentarijum kojim ova teorija raspolaže, u nastavku će biti operacionalizovani samo oni pojmovi koji su od značaja za analizu u konkretnom slučaju, a koji su definisani samim ključnim rečima ovog rada.

\footnotetext{
${ }^{5}$ Ukratko rečeno, sekuritizacija podrazumeva „,socijalne konstrukcije bezbednosnih pretnji“ (Williams 2003, 513), odnosno proces u kojem sekuritizujući akteri putem govornog akta označavaju određeno pitanje bezbednosnom pretnjom, a čije otklanjanje zahteva hitnu primenu specijalnih mera.
} 
Prema mišljenju autora Kopenhaške škole studija bezbednosti, esencijalnu strukturu svakog RBK odlikuju četiri varijable: njegove granice, anarhična struktura, polarnost (distribucija moći) i socijalna konstrukcija (obrasci (ne)prijateljstva) (Buzan and Wæver 2003, 53). Poslednja varijabla omogućava razlikovanje tri vrste bezbednosnih kompleksa shodno odnosima neprijateljstva i prijateljstva koji karakterišu odnose između država/jedinica koje čine taj RBK. U vezi s tim, može se govoriti o konfliktnoj formaciji, bezbednosnom režimu ili bezbednosnoj zajednici kao tipu RBK u odnosu na ovaj kriterijum socijalne konstrukcije.

Konfliktna formacija oblikovana je strahom od rata i bojazni od upotrebe sile u političkim odnosima između država/jedinica RBK (Buzan and Wæver 2003, 489). Dakle, bitne determinante konfliktne formacije jesu postojanje bezbednosne dileme, međusobna sekuritizacija i oružani sukobi. Tokom 90ih godina XX veka Zapadni Balkan je, bez sumnje, bio vid konfliktne formacije, pri čemu su centralnu konfliktnu zonu u periodu 1991-1995 činile Hrvatska i $\mathrm{BiH}, 1999$. godine SRJ (prvenstveno Kosovo*), a 2001. godine Makedonija. Bezbednosni režim, s druge strane, jeste takav vid bezbednosne međuzavisnosti koga i dalje odlikuju strah od rata i bojazan od upotrebe nasilja $u$ političkim odnosima, ali su ti strahovi i bojazni ublaženi setom dogovorenih pravila ponašanja i očekivanjima da će ta pravila biti poštovana (Buzan and Wæver 2003, 491-491). Dakle, u ovom slučaju i dalje postoji bezbednosna dilema i sekuritizacija i međusobno nepoverenje, ali se kvalitativna razlika ogleda u tome što su države/jedinice postigle dogovor da sarađuju povodom spornih pitanja kako ne bi došlo do oružanog sukoba. Najzad, bezbednosna zajednica predstavlja takav obrazac bezbednosne međuzavisnosti gde države/jedinice ne očekuju niti se pripremaju za upotrebu sile u međusobnim odnosima (Buzan and Wæver 2003, 491). U pitanju je RBK u kome ne postoje bezbednosne dileme, međusobna sekuritizacija niti očekivanje oružanih sukoba, već osnovu regionalne dinamike predstavlja saradnja između država/jedinica koje jedna drugu posmatraju kao saradnike, odnosno (rečeno terminologijom TRBK) kao prijatelje. Svakako, bezbednosna zajednica nije nikada u potpunosti lišena potencijalnih konflikata, ali je njihovo rešavanje kooperativno te se ona nalazi u stalnom procesu izgradnje (Veličkovski Stojanovski 2019, 21). Procesi sekuritizacije su i dalje prisutni, ali sada na jednom višem nivou - $u$ formi kolektivne sekuritizacije koja podrazumeva zajedničku sekuritizaciju zajedničkih pretnji. Karl Dojč i koautori (Karl Deutsch et al.) (1957) smatraju da su zajednički interesi i miroljubivo okruženje za rešavanje konflikata ključni 
za postojanje bezbednosne zajednice, te da u takvoj konstelaciji odnosa države ne mogu da zamisle rat jednih protiv drugih.

Osnovni pravci transformacije jednog RBK mogu biti: održavanje statusa quo, unutrašnja i spoljna transformacija (Buzan and Wæver 2003, 53). Održavanje statusa quo podrazumeva izostanak bilo kakvih bitnijih promena $\mathrm{u}$ esencijalnoj strukturi određenog RBK. Unutrašnja transformacija podrazumeva takve promene esencijalne strukture određenog RBK koje svoj izvor imaju unutar postojećih granica tog RBK (poput promena anarhične strukture regionalnim integracijama, promena polariteta dezintegracijom neke države, osvajanjem država unutar tog (pot)kompleksa ili promena dominantnih obrazaca (ne)prijateljstva usled ideoloških preokreta ili ratnog zamora). Spoljna transformacija podrazumeva takve promene esencijalne strukture određenog RBK koje svoj izvor imaju van granica tog (pot)kompleksa, ili pak promene samih granica RBK (poput osvajanja novih teritorija, savezništava ili ujedinjenja sa državama/jedinicama drugih RBK, dodavanjem/isključivanjem država/jedinica, ili pak spajanjem dva RBK u jedan). Imajući u vidu ove trajektorije, kao i ključne karakteristike različitih RBK u kontekstu obrazaca (ne)prijateljstva, na samom kraju rada biće ponuđena analiza mogućih scenarija transformacije Zapadnobalkanskog regionalnog bezbednosnog potkompleksa.

\section{Zapadni Balkan kao regionalni bezbednosni potkompleks}

Regionalni bezbednosni potkompleks (u daljem tekstu: RBPK) suštinski predstavlja isto što i regionalni bezbednosni kompleks, s tom razlikom da je potkompleks čvrsto ugrađen u veći kompleks (Buzan and Wæver 2003, 51, 378), kao što je npr. Zapadni Balkan u Evropski RBK ili Levant u Bliskoistočni. Tako RBPK zapravo predstavlja "polu-nivo“ unutar regionalnog nivoa, imajući sopstvenu regionalnu dinamiku koja ga čini svojevrsnim analitičkim konceptom (ali i dalje vrlo bezbednosno povezanim i zavisnim od većeg kompleksa u koji je ugrađen).

Analizirajući sve regionalne bezbednosne komplekse i potkomplekse, ${ }^{6}$ Buzen i Vejver zapadnobalkanski podregion i njegovo šire okruženje označili

\footnotetext{
${ }^{6}$ Prema ovim autorima, u svetu postoji devet RBK-a (Severnoamerički, Južnoamerički, Evropski, Bliskoistočni, Centralnoafrički, Južnoafrički, Postsovjetski, Južnoazijski, Istočnoazijski), dva protokompleksa (Zapadnoafrički protokompleks i Rog Afrike), jedan superkompleks (Evroazijski) i nekoliko potkompleksa (Buzan and Wæver 2003, xxvi).
} 
su kao Balkan, a koji je deo Evropskog RBK (centriranog oko EU, prim. aut.) $(2003,395)$. Zapadni Balkan se danas često označava formulom „,bivše države SFRJ minus Slovenija plus Albanija“. Lipovac detaljno razbija predrasude prema kojima se Zapadni Balkan tumači na isključiv način, shodno pokušajima evropskih birokrata da ovaj deo evropskog kontinenta ovim nazivom okarakterišu kao „neintegrisani deo Evrope“ (2016, 165-170). Naime, regionalna bezbednosna dinamika jeste ta koja je ključna u uspostavljanju određenog regionalnog bezbednosnog (pot)kompleksa, odnosno opipliva bezbednosna međuzavisnost koja se uspostavlja između država/jedinica koje su geografski blizu. Shodno TRBK, regionalne bezbednosne komplekse generišu procesi koji se dešavaju „odozdo-na gore“. Drugim rečima, svaki $\mathrm{RB}(\mathrm{P}) \mathrm{K}$ potekao je iz strahova i aspiracija pojedinačnih država/jedinica koje ga tvore (a koji najvećim delom proističu iz njihovih unutrašnjih karakteristika) (Buzan and Wæver 2003, 43). Dodatno, ,"trajnost" bezbednosnih karakteristika određenog (pod)regiona ogleda se u činjenici da bi bezbednosna dinamika $u$ takvom RB(P)K postojala čak i onda kada drugi (spoljni, prim. aut.) akteri ne bi na nju uticali (Buzan and Wæver 2003, 47). Tako da je prvi argument prema kome je EU (tačnije, evropske birokrate) „stvorila“ RBPK Zapadni Balkan suštinski neodrživ, budući da su postojeće zapadnobalkanske države/jedinice posedovale (i poseduju) znatnu bezbednosnu međuzavisnost koja prevazilazi puki kriterijum evropske integracije. Naime, postojeći obrasci (ne)prijateljstva koji odlikuju Zapadnobalkanski RBPK rezultat su odnosa koji su se, kroz različite periode, razvijali između država povodom određenih pitanja, kao što su ideološka pitanja, duboke istorijske i političke veze, rešavanje pograničnih sporova itd. (Kovačević 2011, 55). Osim toga, termin Zapadni Balkan nije kovanica evropskih birokrata i novijeg datuma kako se to često pogrešno misli - upotreba ovog termina seže do XIX veka kada se ovim pojmom označavao neuralgični zapadni deo balkanskog poluostrva (primarno u vidu Krajine, Bosne, Hercegovine, Dalmacije i Crne Gore) (Svilar 2010, 504), da bi se vremenom, usled izgradnje zajedničke države, „prelio" i na one delove koji danas čine Zapadni Balkan - bivše državeSFRJ minus Slovenija plus Albanija. ${ }^{7,8}$ Osim

\footnotetext{
${ }^{7}$ Pomenuto svakako ne znači odricanje činjenice da je termin „došao“ sa anglosaksonskog područja - ovde je samo bitno naglasiti kako je pogrešno uvreženo mišljenje da su evropske birokrate te koje su skovale termin Zapadni Balkan. Više o genezi ovog pojma videti u: Svilar 2010.

${ }^{8}$ Albanija svakako nije predstavljala sastavni deo SFRJ, ali ju je, zbog visokog stepena involviranosti u pitanje Kosova* i mnogih drugih bezbednosnih pitanja imanentnih Zapadnom Balkanu, opravdano smatrati delom Zapadnobalkanskog RBPK.
} 
toga, članstvo u EU (iako jedan od najznačajnijih) nije i presudan činilac (ne)svrstavanja određene države/jedinice u okvir Zapadnobalkanskog regionalnog potkompleksa. Stoga Hrvatska, iako predstavlja članicu EU, zaslužuje da bude tretirana kao deo Zapadnobalkanskog potkompleksa usled dubokih istorijskih, političkih, bezbednosnih, ekonomskih i kulturoloških veza koje ostvaruje sa ostalim susednim državama. Na kraju, Lipovac ističe kako je na ovako shvaćen način RBPK Zapadni Balkan „kvalitativno drukčiji od Zapadnog Balkana evropskih birokrata" $(2003,168)$ s obzirom na to da je kriterijum članstva u EU, u smislu TRBK, samo jedan od njegovih karakteristika. Drugim rečima, specifična regionalna bezbednosna dinamika na Zapadnom Balkanu daleko je kompleksnija da bi se mogla svesti samo na kriterijum (ne)članstva u Evropskoj uniji. Tako da će se, u konkretnom slučaju, Zapadni Balkan posmatrati shodno formuli „bivša SFRJ minus Slovenija plus Albanija“. Ovakva klasifikacija, naravno, ne znači nužno da druge balkanske zemlje (poput Grčke, Mađarske, Rumunije i Bugarske) ne ostvaruju veze sa zapadnobalkanskim državama - ovde je prvenstveno reč o kvalitativno dubljim i intenzivnijim relacijama između zapadnobalkanskih zemalja koje ga čine odgovarajućim RBPK unutar Evropskog regionalnog bezbednosnog kompleksa i razlikuju od ostalih jedinica u okruženju.

Posmatrano $u$ terminima moći, zapadnobalkanske države mogu se okarakterisati kao male, odnosno kao slabe ukoliko se klasifikuju shodno kriterijumu snage. Takve države karakterišu ograničene mogućnosti te su njihovi bezbednosni interesi i aktivnosti uglavnom usmereni na bliske susede (Buzan and Wæver 2003, 46), što znači da im takvi kapaciteti omogućavaju najdalje regionalno prostiranje i delovanje. ${ }^{9}$ Ovakvi materijalni faktori, $\mathrm{u}$ kombinaciji sa istorijskim, političkim i kulturološkim uslovima karakterističnim za određeni (pod)region, daju posebnu kvalitativnu odliku takvom regionalnom klasteru i omogućavaju analizu njegove (bezbednosne) dinamike na nivou „između sistemskog i nacionalnog“. Drugim rečima, ono što zapadnobalkanske zemlje čini regionalnim potkompleksom u bezbednosnom smislu jeste takav stepen bezbednosne međuzavisnosti koji ih istovremeno povezuje u jedan skup i razlikuje od okolnih bezbednosnih regiona. ${ }^{10}$

\footnotetext{
${ }^{9} \mathrm{Za}$ razliku od supersila i velikih sila koje jedine imaju sposobnost "prodiranja“ (engl. penetration) u susedne regione i delovanja na globalnom nivou.

${ }^{10} \mathrm{Ili}$, kako to Buzen i Vejver navode, RBK specifičnim podstrukturama međunarodnog sistema čine „relativni intenzitet bezbednosne međuzavisnosti između grupe jedinica tog regiona i bezbednosna ravnodušnost između te grupe i drugih jedinica iz okruženja“ $(2003,48)$.
} 
Lipovac takođe govori $\mathrm{u}$ prilog Zapadnom Balkanu kao relativno trajnom RBPK budući da dve fokalne tačke njegove regionalne bezbednosne međuzavisnosti - pitanje statusa Kosova i Metohije i Bosne i Hercegovine najverovatnije neće skoro biti rešene $(2016,168)$. Ova dva najspornija pitanja, naime, dotiču sve zapadnobalkanske zemlje tako da su ,involviranost svih aktera i različiti (nacionalni) interesi u pogledu 'konačnih rešenja' za KiM i $\mathrm{BiH}^{\prime \prime}$ ključni činioci za postojanje Zapadnobalkanskog RBPK (Lipovac 2016, 168), odnosno čine okosnicu bezbednosne međuzavisnosti zapadnobalkanskih država. Ono što ovim pitanjima daje bezbednosnu "težinu“ i tinjajući konfliktni potencijal jesu najpre specifične istorijske i društvene okolnosti poput ratne prošlosti i ratnih zločina, izrazite etničke heterogenosti na malom prostoru, preklapajućih teritorijalnih zahteva i drugih nacionalnih interesa, spornih identitetskih/religijskih pitanja i sl.

Ono što karakteriše Buzenovu i Vejverovu analizu regionalne bezbednosne dinamike na (Zapadnom) Balkanu jeste, između ostalog, pojednostavljen istraživački pristup kompleksnim balkanskim odnosima, ali i česti sporni izvori (Lipovac 2016: 163), što neretko vodi paušalnim i uprošćenim zaključcima. Konkretnije, u svojoj deskripciji balkanske dinamike, autori nigde ne navode klasifikaciju ovog (pod)regiona shodno kriterijumima na osnovu kojih vrše generalne klasifikacije svih ostalih (pot)kompleksa. Međutim, složena zapadnobalkanska regionalna bezbednosna dinamika ne može se posmatrati isključivo kroz materijalističke elemente, odnosno distribuciju moći, imajući u vidu da su sve države koje je generišu male shodno tom kriterijumu, ali i činjenice da je ova dinamika ujedno i posledica već pobrojanih društveno-političkih okolnosti koje baštini konstruktivistička tradicija. Stoga je element socijalne konstrukcije (odnosno obrasci (ne)prijateljstva) ključan $u$ konkretnom slučaju promišljanja zapadnobalkanske bezbednosne dinamike.

Tokom 90-ih godina XX veka Zapadni Balkan je nesumnjivo predstavljao konfliktnu formaciju usled raspada SFRJ i nastanka teritorijalnih sporova praćenih oružanim sukobima, razlikujući se tako u potpunosti od ostatka Evrope. ${ }^{11}$ Buzen i Vejver navode kako su hrvatsko-

\footnotetext{
${ }^{11}$ Buzen i Vejver govore čak o 90-im godinama XX veka kao periodu u kome je Balkan posedovao veliki potencijal da formira poseban $\operatorname{RBK}(2003,377)$, da bi sredinom 90-ih, a naročito nakon 1999. godine, on dobio status RBPK. U takvoj periodizaciji događaja, (Zapadni) Balkan prošao je tri faze u razvoju: zaprečavanje, intervenciju i integraciju (Buzan and Wæver 2003, 395-396).
} 
srpski sukob, sukob tri etničke grupe u $\mathrm{BiH}$, sukob između Albanaca i Srba na prostoru Kosova i Metohije, kao i sukob Makedonaca i Albanaca, zapravo ključni sukobi koji određuju današnju balkansku regionalnu bezbednosnu dinamiku $(2003,384)$, pri čemu ovi obrasci neprijateljstva nisu nužno na nivou bilateralnih, već vrlo često uključuju i više od dve strane $(2003,386)$. Tako se sekuritizujući procesi mogu pratiti na liniji Hrvati-Srbi (u Hrvatskoj i BiH), Srbi-Albanci (na KiM i Južnoj Srbiji), Srbi-Bošnjaci (u Srbiji, BiH i Crnoj Gori), Makedonci-Albanci (u Severnoj Makedoniji) i sl. (Lipovac 2016, 169-170), dok su za rešavanje pitanja Kosova* podjednako zainteresovani Srbi u Srbiji, na KiM-u, BiH, Crnoj Gori, Hrvatskoj, odnosno za pitanje BiH su, pored Srba, zainteresovana i hrvatska i bošnjačka strana u $\mathrm{BiH}$, Hrvatskoj, Crnoj Gori itd. Dakle, ključni problemi koji opterećuju zapadnobalkansku bezbednosnu dinamiku dolaze iz socijetalnog sektora u vidu identitetskih pitanja koja imaju značajan potencijal „prelivanja“ (engl. spillover) i na druge sektore.

Period koji je usledio nakon oružanih sukoba i izgradnje zapadnobalkanskih država odlikovala je sve veća stabilnost (uz zapaženu ulogu EU u tim procesima), a ovaj prostor dobio je epitet relativno stabilnog (pod)regiona sa tinjajućim konfliktnim potencijalom usled nekih značajnih nerešenih pitanja. Kao što je već rečeno, različiti (bilateralni i multilateralni) formati saradnje između zapadnobalkanskih država i sekuritizacija zajedničkih pretnji (što neretko rezultira udruživanjem u borbi protiv istih) najznačajniji su kriterijumi za klasifikaciju Zapadnog Balkana kao bezbednosnog režima. Stoga je, na ovom mestu, neophodno mapirati ključne zajedničke pretnje i kooperativne mehanizme koje ovaj RBPK kvalitativno razlikuju od konfliktne formacije karakteristične za period 90ih godina XX veka.

Kako je prethodno pomenuto, bezbednosne prakse ključnih aktera definišu određeni kompleks $u$ bezbednosnim terminima, dok je na analitičarima da te prakse koje se formulišu i preduzimaju u određenom $\mathrm{RB}(\mathrm{P}) \mathrm{K}$ mapiraju i istraže. Tako pregled strateških dokumenata u oblasti bezbednosti/odbrane zapadnobalkanskih država govori u prilog tome da ove zemlje sekuritizuju gotovo istovetne pojave i procese. ${ }^{12}$ Posvećenost

\footnotetext{
${ }^{12}$ Izuzetak su pojedinačne pretnje karakteristične isključivo za određene države (poput pretnje u vidu protivpravno jednostrano proglašene nezavisnosti Kosova i Metohije kada je u pitanju Republika Srbija).
} 
EU i projektovanom članstvu u ovoj nadnacionalnoj organizaciji vidljiva je i u ovom segmentu usklađivanja strateških bezbednosnih dokumenata sa onim evropskim (odnosno, sa bezbednosnim strategijama EU iz 2003. i 2016. godine). ${ }^{13} \mathrm{U}$ tom smislu, kao ključne bezbednosne pretnje zapadnobalkanskih država izdvojene su oružana agresija, organizovani kriminal, terorizam, različiti vidovi ekstremizma, nerešena pitanja teritorijalnog razgraničenja sa susednim državama, proliferacija konvencionalnog i oružja za masovno uništenje, sajber pretnje, ilegalne migracije, energetska zavisnost, negativni trendovi demografskog razvoja, elementarne nepogode, epidemije i pandemije zaraznih bolesti, degradacija životne sredine i sl. (Nacionalna koncepcija za bezbednost i odbrana 2003; NSS RA 2004; Sigurnosna politika BiH 2006; Strategija RH 2017; Strategija CG 2018; Strategija RS 2019).$^{14}$ Moguće je primetiti da, iako su mnoge savremene bezbednosne pretnje deteritorijalizovane, veliki broj njih i dalje poseduje značajnu prostornu dimenziju (Paraušić i Stojanović 2017, 98). S obzirom na to da je bezbednost i dalje $\mathrm{u}$ velikoj meri vezana za teritoriju, bezbednosne pretnje se brže i lakše prenose kraćim distancama (dakle između fizički bliskih država), što naročito postaje važno u kontekstu regionalne bezbednosti i kada se uzme u obzir efekat "prelivanja“ pretnji iz jednog sektora bezbednosti u drugi. Prošlost ovog regiona opterećena različitim izazovima, a koja može biti izvor daljih tenzija, prepoznata je kao problematična i u samim bezbednosnim strategijama zapadnobalkanskih država, ali i činjenica da ovakve zajedničke bezbednosne zabrinutosti mogu biti tretirane samo putem odgovarajućih mehanizama saradnje.

Povodom rešavanja zajedničkih pretnji koje imaju potencijal "prelivanja“ izvan nacionalnih granica, države se uglavnom međusobno udružuju i sarađuju. Osim toga, pretnje sa ovakvim efektom potencijalno mogu imati posledice ne samo po nacionalni i regionalni već i po sistemski nivo. $U$ tom smislu, ne treba prenebregnuti uključenost zapadnobalkanskih zemalja u posebne bezbednosne strukture putem kojih sarađuju bilo međusobno bilo

${ }^{13}$ Osim evropskih, postoji i usklađivanje sa ključnim strateškim dokumentima NATO kod onih zapadnobalkanskih država koje su punopravne članice ove Alijanse.

${ }^{14}$ Pomenuto svakako treba uzeti s rezervom budući da su strategije tri države (Bosne i Hercegovine, Severne Makedonije i Albanije) u odnosu na strategije Srbije, Hrvatske i Crne Gore starije za 14 do 16 godina. Međutim, s obzirom na sličnosti u pogledu identifikovanih pretnji u potonjim, "mlađim“ strategijama, kao i slično strateško okruženje koje zapadnobalkanske zemlje dele, moguće je izvesti gorepomenute generalizacije. 
sa postojećim velikim silama na ovom prostoru. ${ }^{15}$ Popis najznačajnijih regionalnih organizacija i inicijativa čije su članice/posmatrači, između ostalih, i zapadnobalkanske države (Tabela 1), govori u prilog ovoj tezi. Tako prepoznate zajedničke pretnje, poput organizovanog kriminala, korupcije, ilegalnih migracija, ili pak ugrožavanja životne sredine, rezultiraju umrežavanjem bezbednosnih struktura država Zapadnog Balkana. Na ovom mestu nameće se još jedan zaključak - nacionalne bezbednosti zapadnobalkanskih zemalja ne mogu biti razložno analizirane (niti shvaćene) bez njihovog postavljanja u kontekst zapadnobalkanske regionalne bezbednosne dinamike, što zapravo korespondira sa konstatacijom da nacionalne bezbednosti ne mogu biti samostalne budući da je „bezbednosna dinamika suštinski relaciona“ (Buzan and Wæver 2003, 43). Stoga je njih (nacionalne bezbednosti) neophodno analizirati unutar podsistemskog (regionalnog) konteksta. Ovo još više dolazi do izražaja u kontekstu pomenutog efekta "prelivanja“ pretnji iz jednog bezbednosnog sektora $u$ drugi i njihovog prekograničnog karaktera.

Kada je u pitanju saradnja između zapadnobalkanskih država, ne može se prenebregnuti činjenica da ove zemlje danas ostvaruju značajne vidove saradnje (uz, doduše, značajano uslovljavanje Evropske unije). Posebno pitanje je postoji li čisto zapadnobalkanska inicijativa ili su gotovo svi formati saradnje uslovljeni "spolja“, što svakako problematizuje to pitanje u smislu doživljaja nametanja saradnje od strane spoljnih aktera. No, gotovo sve zapadnobalkanske zemlje $\mathrm{u}$ svojim strateškim dokumentima jesu opredeljene za održavanje i razvijanje dobrosusedskih odnosa. Bilateralni odnosi i određene regionalne inicijative pokrivaju najrazličitije oblasti - od čisto ekonomskih, infrastrukturnih, energetskih, ekoloških do političkih i bezbednosnih. U nastavku teksta (Tabela 1) dat je unakrsan pregled trenutnog angažovanja zapadnobalkanskih država $u$ regionalnim inicijativama gde su predstavljene isključivo one koje podrazumevaju prisustvo svih zapadnobalkanskih zemalja (ili gotovo svih).

${ }^{15}$ U vezi sa ovim, svakako je najznačajnija organizacija NATO u koju su zapadnobalkanske zemlje uključene bilo punopravnim članstvom bilo putem mehanizma Partnerstva za mir. 
Tabela 1: Regionalne organizacije i inicijative čije su članice/posmatrači države ZB

\begin{tabular}{|c|c|c|}
\hline RB & Naziv regionalne organizacije/inicijative & Države $Z^{16}$ \\
\hline 1. & Centralno-evropska inicijativa (CEI) & {$[1],[2],[3],[4],[5],[6]$} \\
\hline 2. & $\begin{array}{l}\text { Organizacija za crnomorsku ekonomsku saradnju } \\
\text { (BSEC) }\end{array}$ & {$[3],[5],[6]$} \\
\hline 3. & Proces saradnje ministara odbrane JIE (SEDM) & [1], [2], [3], [4], [5], [6] \\
\hline 4. & Inicijativa za saradnju u JIE (SECI) & {$[1],[2],[3],[4],[5],[6]$} \\
\hline 5. & Proces saradnje u JIE (SEECP) & {$[1],[2],[3],[4],[5],[6]$} \\
\hline 6. & Evro-mediteransko partnerstvo (EuroMed) & [1], [2], [4] \\
\hline 7. & Centar za sprovođenje zakona u JIE (SELEC) & [1], [2], [3], [4], [5], [6] \\
\hline 8. & Jadransko-jonska inicijativa (AII) & {$[1],[2],[3],[4],[5],[6]$} \\
\hline 9. & Regionalna antikorupcijska inicijativa & [1], [2], [3], [4], [5], [6] \\
\hline 10. & $\begin{array}{l}\text { Inicijativa za pripravnost i prevenciju katastrofa } \\
\mathrm{u} \text { JIE (DPPI) }\end{array}$ & {$[1],[2],[3],[4],[5],[6]$} \\
\hline 11. & Centar za bezbednosnu saradnju (RACVIAC) & [1], [2], [3], [4], [5], [6] \\
\hline 12. & Zdravstvena mreža JIE (SEEHN) & [2], [3], [4], [5], [6] \\
\hline 13. & Udruženje šefova policije JIE (SEPCA) & [1], [2], [3], [4], [5], [6] \\
\hline 14. & Savetodavna grupa tužilaca JIE (SEEPAG) & [1], [2], [3], [4], [5], [6] \\
\hline 15. & Jadranska povelja & [1], [2], [3], [4], [5], [6] \\
\hline 16. & Transportni opservatorij za JIE (SEETO) & {$[1],[2],[3],[4],[5],[6]$} \\
\hline 17. & Inicijativa za migracije, azil i izbeglice (MARRI) & {$[2],[3],[4],[5],[6]$} \\
\hline 18. & Inicijativa za reformu obrazovanja u JIE & [1], [2], [3], [4], [5], [6] \\
\hline
\end{tabular}

${ }^{16}$ Kako cilj nije prikazati apsolutno sve članice/posmatrače pobrojanih inicijativa i organizacija, navedene su isključivo zapadnobalkanske države kao njihove članice/ posmatrači i to prema sledećem redosledu: [1] Hrvatska, [2] BiH, [3] Srbija, [4] Crna Gora, [5] Severna Makedonija, [6] Albanija. 


\begin{tabular}{|c|c|c|}
\hline RB & Naziv regionalne organizacije/inicijative & Države ZB \\
\hline 19. & $\begin{array}{l}\text { Stalna radna grupa za regionalni ruralni razvoj } \\
\text { u JIE (SWG) }\end{array}$ & {$[2],[3],[4],[5],[6]$} \\
\hline 20. & Međunarodna komisija za sliv reke Save (ISRBC) & {$[1],[2],[3]$} \\
\hline 21. & Savet ministara kulture JIE & {$[1],[2],[3],[4],[5],[6]$} \\
\hline 22. & CEFTA & [2], [3], [4], [5], [6] \\
\hline 23. & Centar javnih službi za zapošljavanje zemalja JIE & {$[1],[2],[3],[4],[5],[6]$} \\
\hline 24. & Sekretarijat Energetske zajednice & [2], [3], [4], [5], [6] \\
\hline 25. & Zajedničko evropsko vazduhoplovno područje & {$[1],[2],[3],[4],[5],[6]$} \\
\hline 26. & Konvencija o policijskoj saradnji u JIE & {$[1],[2],[3],[4],[5],[6]$} \\
\hline 27. & Jedinstveno evropsko nebo u JIE & {$[1],[2],[3],[4],[5],[6]$} \\
\hline 28. & Regionalni savet za saradnju (RCC) & {$[1],[2],[3],[4],[5],[6]$} \\
\hline 29. & Investicioni fond za Zapadni Balkan & {$[1],[2],[3],[4],[5],[6]$} \\
\hline 30. & Regionalna škola za javnu upravu & [2], [3], [4], [5], [6] \\
\hline 31. & Strategija EU za Podunavlje (EUSDR) & {$[1],[2],[3],[4],[5],[6]$} \\
\hline 32. & Brdo-Brioni proces & {$[1],[2],[3],[4],[5],[6]$} \\
\hline 33. & Berlinski proces & {$[1],[2],[3],[4],[5],[6]$} \\
\hline 34. & Strategija EU za Jadransko-jonski region (EUSAIR) & {$[1],[2],[3],[4],[5],[6]$} \\
\hline 35. & Fond za Zapadni Balkan (WBF) & {$[2],[3],[4],[5],[6]$} \\
\hline 36. & Regionalna kancelarija za saradnju mladih (RYCO) & [2], [3], [4], [5], [6] \\
\hline 37. & Regionalno ekonomsko područje & [2], [3], [4], [5], [6] \\
\hline 38. & Mini-Šengen & {$[3],[5],[6]$} \\
\hline 39. & Zajedničko regionalno tržište & [2], [3], [4], [5], [6] \\
\hline
\end{tabular}

Izvor: BPRG 2021; sopstveno istraživanje. 


\section{ULOGA EVROPSKE UNIJE U TRANSFORMACIJI RBPK ZAPADNI BALKAN}

Za razliku od malih i slabih država čiji kapaciteti omogućavaju njihovo najdalje regionalno delovanje, mehanizam "prodora“ (penetracije) karakteriše prisustvo globalnih sila u različitim regionima širom sveta. ${ }^{17}$ Budući da, kako je prethodno pomenuto, obrasci sukoba prisutni u nekom RBK potiču od autohtonih faktora (odnosno unutrašnje bezbednosne dinamike), uobičajeno je da spoljne sile ne mogu značajno uticati na desekuritizaciju i reorganizaciju takvog regiona (Buzan and Wæver 2003, 47). Međutim, unipolarnost predstavlja izuzetak od tog pravila. Naime, ,"kada su dve strane uključene u lokalni sukob zavisne od iste spoljne sile, moguće je da ta sila izvrši pritisak da suprotstavljene strane otpočnu mirovni proces" (Buzan and Wæver 2003, 47). To je, npr. bio slučaj sa Paktom za stabilnost Jugoistočne Evrope 1999. godine gde je došla do izražaja upravo evropska unipolarnost, odnosno ključna spoljna sila u vidu Evropske unije. Takva unipolarnost, dakle, podrazumeva postojanje jedne spoljne sile zbog koje bi drugi akteri pristali na određene ustupke i međusobnu saradnju. Ova konstatacija značajna je i u kontekstu postavljene hipoteze, odnosno analize odlučujućeg uticaja EU i njenih pristupnih procesa $\mathrm{u}$ reorganizaciji Zapadnobalkanskog RBPK $\mathrm{u}$ pravcu njegove izgradnje kao bezbednosnog režima.

Kako se može primetiti, Buzen i Vejver $(2003,52)$ naglašavaju ulogu globalnih sila u regionalnim konfliktnim obrascima. U vezi s tim, bitno je napomenuti da je prostor na kome egzistiraju zapadnobalkanske države umnogome zavisio od interesa koje su ostvarivale (i ostvaruju) velike sile. Na ovom mestu svakako treba dotaći i ključne međunarodne aktere prisutne na ovom prostoru u vidu SAD, EU, Rusije, Kine, pojedinih evropskih država, Turske i NATO. Drugim rečima, Zapadni Balkan danas (kao ni ranije) nije oslobođen prisustva velikih sila - ovim prostorom dominiraju EU i SAD (NATO), ali postoji i alternativa u obliku Rusije i Kine. Glavna

\footnotetext{
${ }^{17}$ Pojava „prodora“ ili penetracije postoji kada spoljne sile vrše bezbednosno usklađivanje sa državama/jedinicama unutar određenog RBK (Buzan and Wæver 2003, 46). Sa druge strane, „prekrivanje“ se dešava kada interesi velike sile prevazilaze puko prodiranje i toliko dominiraju u postojećem RBK da njegovi lokalni obrasci bezbednosnih odnosa praktično prestaju da postoje (Buzan and Wæver 2003, 61). S obzirom na to da prodor/prekrivanje može doći samo od strane spoljne, globalne sile, ove mehanizme ne treba mešati sa silom koja predstavlja pol centriranog RBK.
} 
pretpostavka Buzena i Vejvera, prema kojoj su SAD na prvom mestu kada se raspravlja o ključnim faktorima međunarodne zajednice na balkanskom prostoru $(2003,387)$, svakako je uzdrmana navedenom hipotezom da EU predstavlja dominantnu veliku silu na teritoriji zapadnobalkanskih država. Međutim, njihov stav nije i nužno netačan - SAD i NATO zaista jesu bili ključni spoljni akteri u zapadnobalkanskoj bezbednosnoj dinamici krajem 90-ih godina XX veka, ${ }^{18}$ ali je uloga EU u ovom potkompleksu postala odlučujuća nakon početka 2000-ih. EU je na ovom prostoru prisutna primarno kroz sopstvene integracione, pristupne i reformske politike što njen uticaj čini najvidljivijim upravo na Zapadnom Balkanu više nego u bilo kom drugom (pod)regionu. Takođe, Buzen i Vejver jasno potcrtavaju da su na zapadnobalkanskom prostoru SAD i Rusija prisutne ne per se, već isključivo kroz sopstvenu „evropsku projekciju“ $(2003,391)$. Drugim rečima, (Zapadni) Balkan je primarno viđen kao evropska bezbednosna laboratorija - prostor za rešavanje posthladnoratovskih evropskih bezbednosnih pitanja, poput odnosa između EU i NATO, odnosno između Zapada i Rusije. Međutim, u pogledu ovih ključnih aktera, a u vezi sa aktuelnim trendovima, ugrubo se mogu izvesti sledeći zaključci - interesovanje SAD za ovaj prostor primarno je vezano za kosovsko pitanje, ${ }^{19}$ dok je prisustvo Rusije trenutno najvidljivije kroz energetsku prizmu (uz nešto jači uticaj u Srbiji i, donekle, $\mathrm{BiH}$ ); zainteresovanost Kine za ovaj region (tačnije za ovaj region unutar Inicijative 17+1) poraslo je tokom poslednje decenije, uz napomenu da je Kina na ovim prostorima trenutno prisutna isključivo ekonomski i da (za sada) ne pokazuje značajniju političko-bezbednosnu zainteresovanost; Turska tradicionalno iskazuje interesovanje za zapadnobalkanski prostor primarno oličen u vidu Sandžaka i Kosova* u Srbiji, kao i BiH, prvenstveno zbog identitetske/religijske bliskosti sa bošnjačkim stanovništvom, ali bez zapaženijeg uspeha usled njenih skromnijih kapaciteta kao regionalne sile, ${ }^{20}$

${ }^{18}$ Navedenom stavu doprinosi i sam period bezbednosne analize, kao i datum Buzenove i Vejverove publikacije (2003), odnosno period koji se poklapa sa krajem oružanih sukoba na Zapadnom Balkanu.

${ }^{19}$ Ovaj interes za kosovsko pitanje primarno je oličen $u$ vidu instituta specijalnog izaslanika za kosovsko pitanje, kao i dalje prisutnih snaga KFOR na Kosovu*. Osim toga, skoro potpisan Vašingtonski sporazum o normalizaciji ekonomskih odnosa između Beograda i Prištine (2020) dodatno govori o zainteresovanosti SAD za rešavanje ovog pitanja. Međutim, kako je ovaj Sporazum potpisan za vreme poslednjeg Trampovog mandata, ostaje da se vidi odnos Bajdenove administracije prema ovom pitanju.

${ }^{20}$ Svi prethodno opisani spoljni akteri kategorisani su kao velike sile. 
unutrašnjih političkih problema i omeđenosti od Zapadnog Balkana Bugarskom i Grčkom. Tako se uloga EU svakako nameće kao ključna usled različitih formata u kojima je prisutna na Zapadnom Balkanu, kao i zbog činjenice da sve države koje tvore Zapadnobalkanski RBPK jesu opredeljene za članstvo u Evropskoj uniji i samim tim u njene „političke, ekonomske i bezbednosne strukture“ (Veličkovski Stojanovski 2019, 9).

Teza Buzena i Vejvera da su ishod oružanih sukoba u bivšoj SFRJ tokom 90-ih godina (a samim tim i tip RBPK) odlučili sekuritizujući potezi spoljnih sila, a ne unutrašnja (zapadno)balkanska dinamika $(2003,377)$, svakako da dovodi u pitanje pomenuti stav o unutrašnjoj bezbednosnoj dinamici kao ključnom faktoru za uspostavljanje određenog RB(P)K. Međutim, kako je već pomenuto, autori ne odriču uticaj globalnih sila u procesima koji bezbednosnu dinamiku određenih (pod)regiona guraju u pravcu konfliktne formacije ili bezbednosnog režima (Lipovac 2016, 168). Štaviše, usled prisustva nekoliko globalnih sila u anarhičnom međunarodnom sistemu, kao i (Evropskoj uniji bliskog) geografskog položaja Zapadnog Balkana, takav uticaj je i očekivan..$^{21}$ Drugim rečima, "regionalni konfliktni obrasci oblikuju puteve intervenisanja globalnih sila" (Buzan and Wæver 2003, 52). ${ }^{22} \mathrm{U}$ vezi s tim, uloga EU na prostoru Zapadnog Balkana svakako je bila jedna od ključnih u procesu podsticanja izgradnje bezbednosnog režima (naročito nakon 2000-ih). Dodatno, ako se politika proširenja EU (definisana najpre kroz sporazume o stabilizaciji i pridruživanju sa zapadnobalkanskim državama) posmatra kao mehanizam „prodora“ u zapadnobalkansku regionalnu bezbednosnu dinamiku (Kovačević 2011, 57), onda ona (EU) nesumnjivo ostvaruje ključnu ulogu u ovom potkompleksu, a s obzirom na spoljnopolitički kurs država Zapadnog Balkana usmeren ka članstvu u ovoj nadnacionalnoj organizaciji i prihvaćenost svih uzusa po kojima ona funkcioniše.

Da EU danas čini ključnog spoljnog aktera Zapadnobalkanskog RBPK naglašava najpre činjenica da je sam Zapadni Balkan deo većeg, Evropskog RBK čiji je glavni (i jedini) pol upravo Evropska unija. Osim toga, ,evropska

${ }^{21}$ Dakle, međupovezanost anarhične međunarodne strukture i posledica ravnoteže moći, $\mathrm{s}$ jedne strane, i lokalne geografske blizine, s druge strane (Buzan and Wæver 2003, 45), jeste ono što utiče na formiranje $\mathrm{RB}(\mathrm{P}) \mathrm{K}$ i daje novi kvalitet njegovoj unutrašnjoj dinamici.

${ }^{22}$ Sprega nacionalnog, regionalnog i globalnog možda je najoličenija u konstataciji da se bezbednost države i intervencije globalnih sila mogu razumeti samo razumevanjem regionalne bezbednosne dinamike (Wæver 2005, 156). 
perspektiva" država Zapadnog Balkana zvanično je i potvrđena 2003. godine na Samitu EU u Solunu putem tzv. Solunske agende za Zapadni Balkan (EC 2003). U svom istraživanju baziranom na tri studije slučaja (Hrvatska, Srbija i BiH), Anastasia Kudlenko (Anastasiia Kudlenko) (2018) ukazala je na presudnu ulogu EU u procesima reformi sektora bezbednosti na Zapadnom Balkanu. U tom smislu, EU se smatra ključnim drajverom niza reformi koje su zahvatile zapadnobalkanske države počev od 2000-ih godina. ${ }^{23} \mathrm{U}$ sličnom maniru, Kovačević (2011) posmatra EU kao najznačajnijeg „penetratora“ u bezbednosnu dinamiku Zapadnog Balkana u periodu nakon raspada SFRJ, odnosno evropski proces proširenja kao najznačajniji mehanizam pomoću koga Evropska unija ostvaruje uticaj u ovom regionu. Dodatno, sveobuhvatnim istraživanjem svih država koje čine Zapadni Balkan, Veličkovski Stojanovski (2019) ustanovila je da je upravo EU primarni faktor koji je pomogao uspostavljanju bezbednosnog režima na Zapadnom Balkanu u vojno-bezbednosnom, diplomatskom, ekonomskom i simboličkom aspektu (odnosno aspektu meke moći). Kako ova autorka navodi, danas je Zapadni Balkan bliži konfliktnoj formaciji nego bezbednosnoj zajednici „,zbog veoma slabog napretka u rešavanju sporova, spore implementacije mirovnih sporazuma, odsustva volje da se sprovedu demokratske reforme, veoma slabe regionalne saradnje, političke nestabilnosti, ekonomske stagnacije, diskriminacije manjina i široko rasprostranjene međuetničke netrpeljivosti“ (2019, rezime). Međutim, konfliktni potencijal regiona (primarno oličen kroz pitanja budućeg statusa Kosova* i $\mathrm{BiH}$ ), iako prisutan nije i nužno odlučujući - on danas predstavlja tek dovoljan kriterijum za poimanje Zapadnog Balkana u terminima bezbednosnog režima.

Uloga EU na zapadnobalkanskom prostoru možda se najbolje može razumeti kroz mehanizam upravljanja (engl. governmentality). Originalno shvaćen kao izvoz evropskih pravila i vrednosti izvan sopstvenih granica, ovaj mehanizam objašnjava i trenutnu politiku uslovljavanja EU na Zapadnobalkanskom RBPK. Svi pristupni mehanizmi EU, počev od iniciranja Procesa stabilizacije i pridruživanja 1999. godine i prvog samita država Zapadnog Balkana u Zagrebu 2000. godine, preko pomenute Solunske agende (2003) pa sve do poslednje "Strategije kredibilne perspektive proširenja i pojačanog angažovanja EU na Zapadnom Balkanu“ (2018), naglašavaju ključne principe i vrednosti EU i potcrtavaju evropsku

${ }^{23}$ Tačnije od 2003. godine usled preuzimanja vojnih misija Althea u BiH i Concordia $\mathrm{u}$ Makedoniji, postajući tako sukcesor vojnih misija Severnoatlantske alijanse. 
perspektivu ovog (pod)regiona. Proces stabilizacije i pridruživanja, između ostalog, predstavlja i jedan vid uslovljavanja zapadnobalkanskih država od strane EU u cilju ostvarivanja jake regionalne saradnje i minimizacije rizika od nastanka potencijalnih konflikata. Zauzvrat, ispunjavanjem predviđenih kriterijuma, zapadnobalkanske države postepeno stiču uslove da postanu punopravne članice ove nadnacionalne organizacije. Osim što godišnji izveštaji Evropske komisije o napretku u procesu pristupanja država kandidata Evropskoj uniji predstavljaju neophodnu birokratsku stavku, oni su značajni i iz jednog drugog razloga - eksplicitna potreba za usaglašavanjem politika zemalja kandidata sa evropskim postaje osnova upravljanja EU i izvan sopstvenih granica u vrednosnom smislu, a zaključci Komisije bitan deo javnih narativa političkih elita u državama kandidatima.

Već je pomenuto da "prodor" spoljnih sila može biti indirektan (najrazličitije vrste pomoći državama) i direktan (učešće stranih vojnih snaga, ekonomska pomoć itd.) (Kovačević 2011, 55). Vodeći se ovim formatima "prodora", bitno je istaći da su, u vojnom smislu, spoljne sile (prvenstveno EU i SAD) danas na Zapadnom Balkanu prisutne $\mathrm{u}$ formi misija EUFOR Alteja u BiH i UNMIK i KFOR na Kosovu*, uz doduše znatno smanjene kapacitete $\mathrm{u}$ odnosu na period njihovog početnog mandata. Drugim rečima, prisustvo stranih vojnih snaga u BiH i na Kosovu* dodatno govori u prilog tezi da ove dve tačke Zapadnobalkanskog RBPK jesu njegov najosetljiviji deo zbog koga on i dalje poseduje konfliktni potencijal. ${ }^{24}$ Dalje, proces reformi bezbednosnih sektora koji je zahvatio Zapadni Balkan pod pokroviteljstvom EU nakon 2000-ih korespondira sa usaglašavanjem ovih zemalja sa evropskim acquis communautaire $\mathrm{u}$ oblasti spoljne politike, bezbednosti i odbrane tako da se ovaj proces dodatno može posmatrati kao svojevrstan mehanizam „penetracije“ EU u Zapadnobalkanski RBPK. Osim toga, diplomatske inicijative EU, poput Dijaloga Beograd-Priština i Berlinskog procesa, imaju za cilj rešavanje spornih pitanja i podsticanje regionalne saradnje na Zapadnom Balkanu. U smislu ekonomske pomoći, EU se nalazi na prvom mestu kada su u pitanju različiti mehanizmi finansijskog upliva stranih aktera u državama Zapadnog Balkana. Tokom poslednjih dvadeset godina, EU je kroz različite programe, poput CARDS (2000-2006), a potom i Instrumenata pretpristupne pomoći (IPA I i IPA II), ostvarila značajan finansijski uticaj na zapadnobalkanske države. Primera

${ }^{24}$ Dodatno, na ovim prostorima bile su prisutne i evropske civilne policijske misije u vidu EUPM (BiH), Proxima i EUPAT (Makedonija) i EULEX (Kosovo*). 
radi, ukoliko se u obzir uzmu oba perioda IPA instrumenata (2007-2013 i 2014-2020), u proteklih petnaest godina, Hrvatskoj ${ }^{25}$ je bilo namenjeno 998 miliona evra, Bosni i Hercegovini 1.162,2 miliona evra, Srbiji (sa Kosovom*) 4.161,9 miliona evra, Crnoj Gori 5.14,7 miliona evra, Severnoj Makedoniji $1.223,8$ miliona evra i Albaniji 1.230,7 miliona evra (EC n.d.). Za to vreme, prema podacima platnog bilansa dostupnim na internet stranicama zvaničnih institucija zapadnobalkanskih država, ostale spoljne sile (u prvom redu SAD, Rusija i Kina) ostvarile su značajno manje finansijskog upliva u države Zapadnog Balkana. ${ }^{26}$

Prethodno je istaknuto kako su pod pokroviteljstvom EU od početka 2000-ih na Zapadnom Balkanu uspostavljene mnoge inicijative posvećene regionalnoj saradnji. Integrativni proces EU je, ako ne u potpunosti, onda barem najvećim delom uticao na uspostavljanje saradnje između zapadnobalkanskih zemalja povodom najrazličitijih pitanja - od obaveštajnog rada preko jačanja carinske i policijske saradnje i sl. Ova „integrativna“ uloga EU na Zapadnom Balkanu dodatno je pojačana i skorašnjim usvajanjem Ekonomskog i investicionog plana za Zapadni Balkan (tzv. Connectivity Agenda) kojim se predviđa devet milijardi evra za period 2021-2027 (EC COM[2020] 641 final) i 20 milijardi evra u zajmovima za ekonomski oporavak i integraciju zapadnobalkanskih zemalja u oblasti transporta, energije, zeleni i digitalne tranzicije (EC 2020, 5). Kako se može primetiti, razvoj dobrosusedskih odnosa i podsticanje saradnje između zapadnobalkanskih zemalja i dalje ostaje osnova evropskih integracionih i reformskih politika prema ovom delu evropskog kontinenta.

U svetlu skicirane analize, gotovo izvesnom se čini konstatacija Buzena i Vejvera prema kojoj je očigledno da „Balkan neće biti prepušten sam sebi“ gde Zapad (primarno EU, prim. aut.) preuzima glavnu ulogu stabilizatora (2003, 377-378). To je bilo očigledno tokom 90-ih godina u vidu vojnog prisustva na ovom prostoru, a potom i otpočinjanja reformi sektora bezbednosti zapadnobalkanskih zemalja pod pokroviteljstvom EU i njihove

\footnotetext{
${ }^{25}$ Podaci za Hrvatsku se odnose na period 2007-2013 budući da je ona 2013. godine postala članica Evropske unije.

${ }^{26} \mathrm{~S}$ obzirom na to da obim rada ne dozvoljava detaljniji uvid u svaku državu investitora ponaosob, ovi podaci mogu se pronaći putem sledećih izvora: HNB 2021; NBS 2021; CBCG 2021; NBRNM n.d.; BA n.d. Takođe, za poređenje su uzeti isključivo pokazatelji koji se odnose na strane direktne investicije jer one predstavljaju najpoželjniji vid finansijskog upliva jedne države u drugu.
} 
potonje integracije u evropske i NATO strukture. Stoga spoljna sila u vidu EU (odnosno centralizovana institucija u vidu Evropske unije) jeste ključni „penetrator" u RBPK Zapadni Balkan te je, kao takva, odlučujuće uticala na transformaciju Zapadnog Balkana, odnosno na razvoj Zapadnobalkanskog bezbednosnog režima.

\section{Moguće transformacije RBPK Zapadni Balkan}

Način na koji Buzen i Vejver sprovode sopstvenu analizu regionalnih bezbednosnih (pot)kompleksa širom sveta vodio je i ovo istraživanje. Nakon deskriptivnog dela, sledi prediktivni deo o potencijalnim scenarijima kretanja Zapadnobalkanskog RBPK. I dok održavanje statusa quo podrazumeva izostanak bitnijih promena u esencijalnoj strukturi postojećeg RBPK, Buzen i Vejver, govoreći o potencijalnim budućim trajektorijama (Zapadnog) Balkana, ističu kako je najverovatnije da on doživi unutrašnju transformaciju te tako postane deo šireg, Evropskog RBK. Logično, ovakva integracija Zapadnog Balkana u Evropski RBK označila bi i njegovu determinaciju u terminima bezbednosne zajednice budući da EU upravo predstavlja najeklatantniji primer iste. ${ }^{27}$ Stoga je jedan od mogućih pravaca transformacije RBPK Zapadni Balkan upravo njegova unutrašnja transformacija, odnosno njegova potpuna integracija u Evropski RBK. To bi se primarno desilo pristupanjem zapadnobalkanskih država Evropskoj uniji, te nastavak njihove egzistencije i funkcionisanja prema uzusima EU kao bezbednosne zajednice. U tom slučaju, Zapadni Balkan bi se deklarativno mogao okarakterisati kao bezbednosna zajednica (s obzirom na "ugrađenost" $\mathrm{u}$ evropsku bezbednosnu zajednicu), ali bi suštinski predstavljao neki vid nametnute bezbednosne zajednice. Naime, iako određeni formati političke i ekonomske saradnje i institucionalnog povezivanja zaista postoje (uglavnom usled upliva EU), zapadnobalkanske države ne karakteriše određeni vid zajedničkog regionalnog identiteta (niti postoji naznaka da bi se u skorije vreme on mogao razviti), a što je od ključne važnosti za klasifikaciju određenog (pod)regiona kao bezbednosne zajednice. ${ }^{28}$ Imajući $u$ vidu da je za nastanak određenog (pod)regiona $u$

${ }^{27}$ Ovakva klasifikacija ne znači nužno negiranje postojanja konflikata u regionu, već nastojanje za njihovim mirnim rešavanjem uvek i u svakom slučaju.

${ }^{28}$ Đukanović navodi kako je ključna prepreka stvaranju zajedničkog, Zapadnobalkanskog identiteta „kreiranje antagonizujućih identiteta država i nacija Zapadnog Balkana tokom 
terminima predstavljene teorije neophodna bezbednosna dinamika koja se kreće duž vertikale odozdo-na gore, za poimanje Zapadnog Balkana kao bezbednosne zajednice potrebno je da nepostojanje bezbednosne dileme, desekuritizacija suseda i zajednički, regionalni identitet "dolaze“ iznutra, odnosno da budu rezultat interne bezbednosne dinamike. No, kako je već prikazano $u$ analitičkom delu teksta, ne može se odreći značaj EU koja "gura" bezbednosnu dinamiku Zapadnobalkanskog RBPK u određenom smeru. U tom smislu, bezbednosna zajednica koja bi nastala integracijom zapadnobalkanskih država u EU (kao i u NATO strukture), ,"ne bi bila odraz autentične volje“ ovih zemalja, već pre rezultat kompromisa realnih ekonomskih interesa i zahteva spoljnih aktera (Lipovac 2016, 180). Međutim, ovde se opravdano postavlja pitanje - postoji li u međunarodnim odnosima takav institut kao što je "autentična volja“, naročito kada su u pitanju male i slabe države kao što su zapadnobalkanske? Osim toga, pregled strateških dokumenata iz oblasti bezbednosti i odbrane država Zapadnog Balkana i njihove analizirane prakse govore u prilog tome da su ove zemlje eksplicitno privržene integraciji u evropske političke i bezbednosne strukture. Stoga bi u slučaju integracije zapadnobalkanskih zemalja u EU bilo primerenije govoriti o „utapanju“ zapadnobalkanske regionalne bezbednosne dinamike $\mathrm{u}$ širu - evropsku, te gubitku svojevrsne regionalne bezbednosne dinamike koja ga je činila zasebnim RBPK.

Sa druge strane, imajući u vidu postignute rezultate tokom poslednje dve decenije, kao i dominantan uticaj EU, povratak Zapadnog Balkana na konfliktnu formaciju malo je verovatan. Ono što ovom RBPK i dalje daje konfliktni potencijal i epitet bezbednosno osetljivog regiona jesu sveža ratna prošlost i budući statusi Kosova* i BiH. Nijedna od zainteresovanih strana nije $u$ potpunosti zadovoljna trenutnim rešenjima ova dva pitanja, što dugoročno prolongira njihovo finalno rešavanje. Sporadični diskursi o potencijalnim promenama granica samo su dodatni argument koji ide u prilog toj tezi. Stoga ovaj kratak osvrt na potencijalne pravce transformacije Zapadnobalkanskog RBPK dozvoljava da se kao najverovatniji scenario ispostavi upravo održanje statusa quo, odnosno odsustvo bilo kakvih značajnih promena unutar ovog RBPK (barem kratkoročno posmatrano). Imajući u vidu gotovo ujednačene kapacitete zapadnobalkanskih država i u pogledu moći i

raspada bivše jugoslovenske federacije“ $(2015,349)$. Paradoksalno, izvesnije je da se regionalni (zapadno)balkanski identitet gradio na zajedničkim problemima, a ne na zajedničkim interesima (Todorova 1999, 298). 
u pogledu snage, kao i nemogućnost da iste uvećaju u narednom periodu, status quo, odnosno nastavak funkcionisanja Zapadnog Balkana kao bezbednosnog režima, za sada, ispostavlja se kao najizgledniji scenario.

\section{ZAKLJUČAK}

Zapadni Balkan se danas nalazi između konfliktne formacije i bezbednosne zajednice, odnosno predstavlja bezbednosni režim. Postojeći konfliktni potencijal Zapadnog Balkana najpre je vidljiv kroz dva bezbednosna pitanja kao ključnim preprekama za trajno prevazilaženje problema regionalne nestabilnosti - kroz konačno rešenje statusa Kosova i Metohije, s jedne, i statusa Bosne i Hercegovine, s druge strane (uz još poneke teritorijalne sporove i međuetnička trvenja). Međutim, u poređenju sa periodom 90-ih godina XX veka, Zapadni Balkan danas zaista odlikuje veći stepen mira i stabilnosti, ali još uvek ne u toj meri da bi se mogao smatrati bezbednosnom zajednicom. Drugim rečima, današnji formati saradnje između zapadnobalkanskih država, kao i sekuritizacija zajedničkih pretnji koja neretko rezultira udruživanjem ovih država povodom njihovog rešavanja, dovoljan su kriterijum da isti razlikuju od konfliktne formacije, ali ne i za njegovo svrstavanje u red bezbednosnih zajednica. Za potonje je potrebno da države/jedinice koje tvore Zapadnobalkanski RBPK ne sekuritizuju jedna drugu, kao i da poseduju značajan stepen zajedničkog regionalnog identiteta, što trenutno (ili barem u skorijoj budućnosti) još uvek nije izgledno. Sprovedena analiza govori u prilog postavljenoj hipotezi da EU čini ključnog spoljnog aktera koji je (rečeno terminologijom TRBK) "progurao" zapadnobalkansku regionalnu bezbednosnu dinamiku ka bezbednosnom režimu, odnosno uticao na promenu regionalne bezbednosne dinamike u pravcu saradnje između šest država. U pogledu daljih transformacijskih potencijala RBPK Zapadni Balkan, sam čin integracije zapadnobalkanskih zemalja u EU označio bi promene $\mathrm{u}$ esencijalnoj strukturi uspostavljenog RBPK, dok bi EU učinio definitivnom silom i jedinim polom takvog regionalnog klastera. U tom smislu, EU u svakom slučaju predstavlja ključnog spoljnog aktera u kontekstu zapadnobalkanske regionalne bezbednosne dinamike - u slučaju očuvanja statusa quo predstavlja silu penetratora i garanta postojećeg bezbednosnog režima, dok bi u slučaju unutrašnje transformacije RBPK Zapadni Balkan u pravcu eventualne izgradnje bezbednosne zajednice ona (EU) označila 
definitivnu silu i jedini pol, odnosno faktor "gušenja“ do tada postojeće unutrašnje, zapadnobalkanske regionalne bezbednosne dinamike.

\section{BIBLIOGRAFIJA}

Buzan, Barry and Ole Wæver. 2003. Regions and powers: the structure of international security. Cambridge: Cambridge University Press.

[BA] Bank of Albania. n. d. Foreign direct investments flow. https://www. bankofalbania.org/Statistics/External_sector_statistics/Foreign_Direct_ Investments/Foreign_direct_investments_flow.html

[BPRG] Balkans Policy Research Group. 2021. Regionalna saradnja na Zapadnom Balkanu: Komparativna analiza regionalnog ekonomskog područja, „,mini-Šengena“ i zajedničkog regionalnog tržišta. Januar 2021. https://balkansgroup.org/wp-content/uploads/2021/02/Regionalnasaradnja-na-Zapadnom-Balkanu_KOMPARATIVNA-ANALIZAREGIONALNOG-EKONOMSKOG-PODRU\%C4\%8CJA-\%E2\%80\%9E MINI-\%C5\%A0ENGENA\%E2\% 80\%9C-I-ZAJEDNI\%C4\%8CKOGREGIONALNOG-TR\%C5\%BDI\%C5\%A0TA_WEB-1.pdf

[CBCG] Centralna banka CrneGore. 2021. Platni bilans. https://www.cbcg. me /me/statistika/statisticki-podaci/ekonomski-odnosi-sa-inostranstvom /platni-bilans

Deutsch, Karl W., Sidney A. Burrell, Robert A. Kann, Maurice Lee Jr., Martin Lichterman, Raymond E. Lindgren, Francis L. Loewenheim and Richard W. Van Wagenen, eds. 1957. Political Community and the North Atlantic Area: International Organization in the Light of Historical Experience. Princeton: Princeton University Press.

Đukanović, Dragan. 2015. „Zapadni Balkan: stalni usud evropske periferije“. Medunarodni problemi LXVII (4): 349-364.

[EC] European Commission. n.d. European Neighbourhood Policy And Enlargement Negotiations. Overview - Instrument for Pre-accession Assistance. https://ec.europa.eu/neighbourhood-enlargement/ instruments/overview_en

[EC] European Commission. 2003. EU-Western Balkans Summit Thessaloniki. June 21. https://ec.europa.eu/commission/presscorner /detail/en/PRES_03_163 
[EC] European Commission. 2020. An Economic and Investment Plan for the Western Balkans, $\operatorname{COM}(2020) 641$ final, Communication from the Commission to the European Parliament, the Council, the European Economic and Social Committee and the Committee of the Regions, October 6. https:/ / ec.europa.eu/neighbourhood-enlargement/sites/ near/files/communication_on_wb_economic_and_investment_plan_oc tober_2020_en.pdf

[EC] European Commission. 2020. Investments for the Future: EU Connectivity Agenda for the Western Balkans. November 2020. https://wbif.eu/storage/app/media/Library/6.\%20Connectivity\%20 Agenda/brochure_wb_connectivity_agenda_en.pdf

European Commission. n.d. "Stability Pact for South-Eastern Europe". Accessed 13 April 2021. https://ec.europa.eu/neighbourhoodenlargement/policy/glossary/terms/stability-pact_en

[HNB] Hrvatska narodna banka. 2021. Inozemna izravna ulaganja - imovina o zemljama ulaganja. https://www.hnb.hr/statistika/statistickipodaci/sektor-inozemstva/inozemna-izravna-ulaganja

Kovačević, Marko. 2011. „Uticaj izgradnje države na bezbednosnu dinamiku $\mathrm{u}$ okviru teorije regionalnog bezbednosnog kompleksa“. Bezbednost Zapadnog Balkana 6 (21): 51-61.

Kudlenko, Anastasiia. 2018. The impact of the EU on security sector reform in the Western Balkans. Doctoral dissertation. Canterbury Christ Church University.

Lipovac, Milan. 2016. Nacionalna bezbednost Republike Srbije u regionalnom bezbednosnom potkompleksu Zapadni Balkan. Doktorska disertacija. Fakultet bezbednosti, Univerzitet u Beogradu.

Nacionalna koncepcija za bezbednost i odbrana. 2003. Службен Весник на Република Македонија, No. 42/2001 i 5/2003 (Jun 11). http:/ / morm.gov. mk/?attachment_id=39383

[NBS] Narodna banka Srbije. 2021. Platni bilans. Strana direktna ulaganja, po zemljama (BPM6). https://nbs.rs/sr_RS/drugi-nivo-navigacije/ statistika/platni_bilans/

[Sigurnosna politika BiH] Sigurnosna politika Bosne i Hercegovine. 2006. Službeni glasnik BiH, No. 88/05 (Februar 6). http://www.mod.gov.ba /slike2014/02.28.20_1_Sigurnosna\%20politika\%20BiH.pdf 
[Strategija CG] Strategija nacionalne bezbjednosti Crne Gore. 2018. Decembar 18. https://zakoni.skupstina.me/zakoni/web/dokumenta /zakoni-i-drugi-akti/522/1814-11450-00-38-18-1-4.pdf

[Strategija RH] Strategija nacionalne sigurnosti Republike Hrvatske. 2017. Narodne novine, No. NN 73/2017 1772 (Jul 14). https://narodnenovine.nn.hr/clanci/sluzbeni/2017_07_73_1772.html

[Strategija RS] Strategija nacionalne bezbednosti Republike Srbije. 2019. Službeni glasnik RS, No. 94 (Decembar 27). https://www.pravnoinformacioni-sistem.rs/SlGlasnikPortal/eli/rep/sgrs/skupstina/ strategija/2019/94/2

[NBRNM] National Bank of the Republic of North Macedonia. n.d. Direct Investment in the Republic of North Macedonia. https:/ / www.nbrm. $\mathrm{mk} / \mathrm{ns}$-newsarticle-direktni-investicii-vo-republika-makedonija -metodologija-bpm6-en.nspx

[NSS RA] The National Security Strategy of the Republic of Albania. 2004. https://www.files.ethz.ch/isn/155586/albania_english-2004.pdf

Paraušić, Ana i Filip Stojanović. 2017. „Geopolitički elementi u strateškim dokumentima u oblasti bezbednosti i odbrane Republike Srbije“. Vojno delo 69 (7): 87-99.

Svilar, Predrag. 2010. ,'Zapadni Balkan' - politički kontekst i medijska upotreba". Sociološki pregled XLIV (4): 503-540.

Todorova, Maria. 1999. Imaginarni Balkan. Beograd: Biblioteka XX vek.

Veličkovski Stojanovski, Ivana. 2019. Uticaj Evropske unije na transformaciju regionalnog bezbednosnog potkompleksa Zapadni Balkan. Doktorska disertacija. Fakultet bezbednosti, Univerzitet u Beogradu.

Wæver, Ole. 2005. "The Constellation of Securities in Europe". In: Globalization, security, and the nation state: paradigms in transition, edited by Ersel Aydinli and James N. Rosenau, 151-174. Albany: State University of New York Press.

Williams, Michael C. 2003. "Words, Images, Enemies: Securitization and International Politics". International Studies Quarterly 47 (4): 511-531. 


\title{
THE WESTERN BALKANS: BETWEEN CONFLICT AND STABILITY
}

\begin{abstract}
Given the complex historical, political and security environment of the Western Balkans, this paper focuses on examining the transformation of this region along with the conflict formation - security community spectrum. Additionally, the role of the EU within this process is analyzed ditto, considering it a key external driver of transformation pathways. Therefore, the main hypothesis could be defined as follows: The Western Balkans was transformed from a conflict formation into a security regime, and the role of the EU was crucial in that process. According to the conceptual tools used in this research, the theoretical framework consists of the Regional Security Complex Theory and its concepts. While the theoretical goal of this paper is directed towards the contribution to the overall discussion on regional security theme and key analytical tools, the empirical goal is dedicated to mapping all those important forms of cooperation between the Western Balkans countries and their common threats that separate them from conflict formation and enable their classification as the security regime. The key research methods refer to the literature review, content analysis of the relevant corpus of research material, as well as the scenario method.

Keywords: The Western Balkans, European Union, Regional Security Complex Theory, Regional Security Subcomplex, conflict formation, security regime, security community, transformation.
\end{abstract}

